\title{
Urdu Language
}

National Cancer Institute

\section{Source}

National Cancer Institute. Urdu Language. NCI Thesaurus. Code C154188.

A Persianised standard register of the Hindustani language that is the official national language of Pakistan. 